\title{
Smad2/3 Upregulates the Expression of Vimentin and Affects Its Distribution in DBP-Exposed Sertoli Cells
}

\author{
Xi Zhang, Xiaogang Wang, Taixiu Liu, Min Mo, Lin Ao, Jinyi Liu, Jia Cao, and Zhihong Cui
}

Institute of Toxicology, College of Preventive Medicine, Third Military Medical University, No. 30, Gaotanyan Road, Shapingba District, Chongqing 400038, China

Correspondence should be addressed to Zhihong Cui; zhihongcui_4@126.com

Received 31 August 2015; Revised 3 December 2015; Accepted 8 December 2015

Academic Editor: Pascal Froment

Copyright (C) 2015 Xi Zhang et al. This is an open access article distributed under the Creative Commons Attribution License, which permits unrestricted use, distribution, and reproduction in any medium, provided the original work is properly cited.

Sertoli cells (SCs) in the testes provide physical and nutritional support to germ cells. The vimentin cytoskeleton in SCs is disrupted by dibutyl phthalate (DBP), which leads to SCs dysfunction. In a previous study, we found that peroxisome proliferator-activated receptor alpha $(\mathrm{PPAR} \alpha)$ influenced the distribution of vimentin by affecting its phosphorylation in DBP-exposed SCs. In the present study, we investigated the role of Smad2/3 in regulating the expression of vimentin in DBP-exposed SCs. We hypothesized that Smad2/3 affects the distribution of vimentin by regulating its expression and that there is cross talk between $\operatorname{Smad} 2 / 3$ and PPAR $\alpha$. The real-time PCR and ChIP-qPCR results showed that SB431542 (an inhibitor of Smad2/3) could significantly attenuate the expression of vimentin induced by DBP in SCs. Phosphorylated and soluble vimentin were both downregulated by SB431542 pretreatment. WY14643 (an agonist of PPAR $\alpha$ ) pretreatment stimulated, while GW6471 (an antagonist of PPAR $\alpha$ ) inhibited, the activity of Smad2/3; SB431542 pretreatment also inhibited the activity of PPAR $\alpha$, but it did not rescue the DBP-induced collapse in vimentin. Our results suggest that, in addition to promoting the phosphorylation of vimentin, DBP also stimulates the expression of vimentin by activating Smad2/3 in SCs and thereby induces irregular vimentin distribution.

\section{Introduction}

Spermatogenesis is an essential process for male reproductive function. In one report, subfertility or infertility was generally due to defects in spermatogenesis [1]. Dibutyl phthalate (DBP) is a plasticizer that is widely distributed in the environment and frequently contacted by human. Previous epidemiological, animal, and molecular studies have shown that DBP disrupted spermatogenesis [2-6]. Spermatogenesis occurs in the seminiferous tubules; SCs are unique somatic cells in the seminiferous tubules, which provide physical and nutritional support for spermatocyte maturation $[7,8]$. Periodically "open" and "closed" junctions between SCs and germ cells mediate the maturation process of spermatocyte [9]. Vimentin is tightly connected to the desmosome structure linking germ cells and SCs. The distribution of vimentin filaments changes dynamically during the seminiferous epithelium cycle [10]. Previous studies have shown that the vimentin cytoskeleton was disrupted in DBP-exposed SCs [11]. However, the mechanism of this process is still unknown.
In our previous study, we found that levels of phosphorylated and soluble vimentin were higher in DBP-exposed SCs compared to GW6471 + DBP-treated SCs [12]. We did not investigate vimentin mRNA expression, but the expression of vimentin may also affect the concentration of soluble vimentin. According to a previous study, vimentin mRNA was upregulated in DBP-exposed SCs [13].

The expression of vimentin mRNA was regulated by Smad2/3 in several other cell lines, such as esophageal squamous cell carcinoma cell lines (e.g., Eca109, EC9706, and KYSE150), squamous cell carcinoma of the head and neck cell line Tu686, skeletal myogenic cell line $\mathrm{C} 2 \mathrm{C} 12$, and normal human epidermal keratinocytes cells. Smad2/3 binds to the Smad binding element in the promoter region of vimentin to regulate its expression [14-17]. In this study, we investigated the role of Smad2/3 in the regulation of vimentin mRNA expression in DBP-exposed SCs.

We hypothesized that Smad2/3 could affect the distribution of vimentin by regulating its mRNA expression in DBPexposed SCs, possibly through cross talk with $\operatorname{PPAR} \alpha$; these 
two factors cooperate to affect the distribution of vimentin. Chromatin immunoprecipitation and quantitative real-time PCR (ChIP-qPCR) analysis was performed to identify the regulatory region in the promoter of vimentin bound by phosphorylated Smad2/3. The distribution of vimentin in SCs after different treatments was determined with immunocytochemistry and immunofluorescence, and treatments with various agonists or antagonists were used to investigate the relationship between $\operatorname{Smad} 2 / 3$ and $\operatorname{PPAR} \alpha$.

\section{Materials and Methods}

2.1. Animal and Reagents. Three-week-old male SpragueDawley (SD) rats were purchased from the Center of Experimental Animals at Third Military Medical University (Chongqing, China). They were used under the 3R (replacement, reduction, and refinement) principles. DBP and $4^{\prime}, 6$-diamidino-2-phenylindole (DAPI) were purchased from Sigma-Aldrich Co. (St. Louis, MO, USA). WY14643 (sc-203314), GW6471 (sc-300779), SB431542 (sc-204265), antibodies for vimentin (V9, sc-6260), p-vimentin (Ser83, sc-16674-R), PPAR $\alpha$ (N-19, sc-1985), p-Smad2/3 (sc-11769), and Smad2/3 (sc-8332) were purchased from Santa Cruz Biotechnology (Santa Cruz, CA, USA). An antibody for $\beta$ actin (AA128), HRP-labeled secondary antibodies (A0216, A0208, and A0181), western/IP cell lysis buffer (P0013), a BCA protein assay kit (P0010), an enhanced chemiluminescent kit (P0018A), a ChIP assay kit (P2078), and a PCR/ DNA purification kit (D0033) were purchased from Beyotime Institute of Biotechnology (Beyotime Institute of Biotechnology, Haimen, China). DyLight 488 AffiniPure Goat AntiMouse IgG $(\mathrm{H}+\mathrm{L})$ was purchased from Earth Ox (San Francisco, CA, USA). $0.22 \mu \mathrm{m}$ PVDF membrane, $0.45 \mu \mathrm{m}$ NC membranes, and the enhanced chemiluminescent kit were purchased from Millipore Corporation (Billerica, MA, USA). The 3,3'-diaminobenzidine (DAB) kit used in immunocytochemical experiments was purchased from Zhongshan Golden Bridge Biotechnology (ZSBiO, Beijing, China). Primers were synthesized by Shanghai Sangon Biological Engineering Technology \& Services Co. (Shanghai, China). The reverse transcription kit (RR047A) was purchased from TaKaRa Biotechnology Co. (Dalian). The quantitative realtime PCR kit (A6001) was purchased from Promega Co., an affiliate of Promega (Beijing) Biotech Co., Ltd.

2.2. Sertoli Cell Preparation. Primary SCs were isolated according to previously described procedures [18-21]. In brief, trypsin (HyClone, Rockford, IL, USA) and collagenase IV (Sigma-Aldrich, St. Louis, MO, USA) were used to digest the scissored testes tissue blocks for $30-60 \mathrm{~min}$ at $37^{\circ} \mathrm{C}$. After stopping the digestion by addition of $10 \%$ FBS (Gibco, USA) containing Dulbecco's modified Eagle's medium/Ham's nutrient mixture F12 (DMEM/F12, 1:1) medium ( $\mathrm{pH} 7.2$ ) (HyClone, Thermo Fisher Scientific, Rockford, IL, USA), the mixture was sieved through sterilized 100 meshes. Newly separated cells were cultured for 48 hours in $10 \mathrm{~cm}$ diameter dishes (Corning, New York, USA) with DMEM/F12, 10\% FBS, and $1 x$ penicillin-streptomycin (Beyotime Institute of
Biotechnology, Haimen, China) in $5 \% \mathrm{CO}_{2}$ at $35^{\circ} \mathrm{C}$. Then, cells were treated with $20 \mathrm{mM}$ Tris- $\mathrm{HCl}$ (pH 7.4) for $2.5 \mathrm{~min}$.

2.3. Cell Culture and Treatments. Approximately $2 \times 10^{6}$ SCs were seeded into $10 \mathrm{~cm}$ dishes. DBP was diluted in DMSO (dimethyl sulfoxide) to $100 \mathrm{mM}$. Ten microliters of DBP was added to each $10 \mathrm{~cm}$ dish, for a final concentration of $100 \mu \mathrm{M}$. Equal volumes of DMSO were added to control dishes. Agonists or antagonists (GW6471, WY14643, and SB431542) were added two hours before DBP treatment at a concentration of $10 \mu \mathrm{M}$, according to previous studies $[14,22,23]$. SCs were treated with DMSO, DBP, SB431542 + DBP, and SB431542 for $24 \mathrm{~h}$ to extract RNA. SCs were treated with DBP, WY14643 + DBP, GW6471 + DBP, or SB431542 + DBP for $0 \mathrm{~h}, 1 \mathrm{~h}, 3 \mathrm{~h}$, $6 \mathrm{~h}, 12 \mathrm{~h}$, and $24 \mathrm{~h}$, respectively, to extract protein. The dosage of DBP was based on the CCK8 and immunofluorescence experiments. In the CCK8 experiment, we added 0, 20, 40, 60, 80,100 , and $200 \mu \mathrm{M}$ of DBP to detect its toxicity in SCs. The results showed that DBP promoted Sertoli cell proliferation in a dose-dependent manner. We selected $100 \mu \mathrm{M}$ because its adverse effect on vimentin in SCs at the $24 \mathrm{~h}$ time point was apparent but not severe enough to interfere with western blotting. We selected a series of time points within $24 \mathrm{~h}$ because the damage induced by DBP to SCs was too severe at $48 \mathrm{~h}$ or $72 \mathrm{~h}$. Moreover, we also took into account the dosage and time points used by other researchers [24].

2.4. Real-Time PCR. RNA was extracted with TRIzol (Invitrogen, USA) from the treated SCs. Concentrations and purity of RNA were quantified by a Nanodrop 2000 (Thermo Fisher Scientific, Rockford, IL, USA). Approximately $1 \mu \mathrm{g}$ total RNA was used to generate the cDNA using the PrimeScript RT Reagent Kit with gDNA Eraser (Perfect Real Time). For the PCR reaction, $7 \mu \mathrm{L}$ nuclease-free water, $10 \mu \mathrm{L}$ GoTaq Probe qPCR Master Mix (2x), and $1 \mu \mathrm{L}$ cDNA and primers were used, respectively, in a $20 \mu \mathrm{L}$ total reaction volume. Real-time PCR was performed using a Bio-Rad IQ5 (Bio-Rad, USA) with a preheated lid up to $105^{\circ} \mathrm{C}$, initial denaturation at $95^{\circ} \mathrm{C}$ for $5 \mathrm{~min}$, and 40 repeats of $\left(95^{\circ} \mathrm{C}\right.$ for $10 \mathrm{~s}, 60^{\circ} \mathrm{C}$ for $\left.30 \mathrm{~s}\right)$, followed by extension at $72^{\circ} \mathrm{C}$ for $5 \mathrm{~min}$, and the data were analyzed using the $2^{(-\Delta \Delta \mathrm{Ct})}$ method. Primers used in this experiment are listed in Table 1.

2.5. ChIP-qPCR. The ChIP assay kit (P2078) used in this experiment was purchased from Beyotime Institute of Biotechnology (Haimen, China). Detailed procedures for ChIP-qPCR were previously described [12]. An anti$\mathrm{p}-\mathrm{Smad} 2 / 3$ antibody was used in this experiment $(1 \mu \mathrm{g})$. Primers used in this experiment were targeted to Smad binding elements (SBE) in promoter regions of vimentin [25]. We designed four pairs of primers flanking SBE-containing sequences, $2000 \mathrm{bp}$ upstream of the transcription start site of vimentin. Primer sequences are listed in Table 1 . After the preliminary experiment, only the primers targeting region -837 to -924 showed high amplification efficiency, so we chose this region for further experiments. The product size was $88 \mathrm{bp}$.

2.6. Western Blotting. Proteins from the SCs were extracted at $0 \mathrm{~h}, 1 \mathrm{~h}, 3 \mathrm{~h}, 6 \mathrm{~h}, 12 \mathrm{~h}$, and $24 \mathrm{~h}$, respectively, after DBP, 
TABLE 1: List of primers for real-time PCR and ChIP-qPCR.

\begin{tabular}{|c|c|c|c|c|}
\hline Primer name & Sequences $\left(5^{\prime}\right.$ to $\left.3^{\prime}\right)$ & $T_{m}\left({ }^{\circ} \mathrm{C}\right)$ & Target & Product size (bp) \\
\hline vimentin_LEFT & GCACCCTGCAGTCATTCAGA & 59 & \multirow{2}{*}{+618 to +699} & \multirow{2}{*}{81} \\
\hline vimentin_RIGHT & GCAAGGATTCCACTTTACGTTCA & 61.2 & & \\
\hline$\overline{\text { actin_LEFT }}$ & CCCTGGCTCCTAGCACCAT & 60 & \multirow{2}{*}{+982 to +1061} & \multirow{2}{*}{79} \\
\hline actin_RIGHT & AGAGCCACCAATCCACACAGA & 60 & & \\
\hline SBE1_LEFT & TTTCATGACGTTTCTTTGTGG & 54.1 & \multirow{2}{*}{-1356 to -1442} & \multirow{2}{*}{87} \\
\hline SBE1_RIGHT & TTAGAGCAGCGATGCAGG & 57.3 & & \\
\hline SBE2_LEFT & GGCGGCAGGGAGACTTAG & 61.9 & \multirow{2}{*}{-1018 to -1101} & \multirow{2}{*}{84} \\
\hline SBE2_RIGHT & CGGGGGAGTCACAAAACA & 57.3 & & \\
\hline SBE3_LEFT & TCTGGGAGGAATGGGATG & 57.3 & \multirow{2}{*}{-972 to -1053} & \multirow{2}{*}{82} \\
\hline SBE3_RIGHT & TGTGGGAGTGTGGAGGGT & 59.6 & & \\
\hline SBE4_LEFT & AGCGAGTTCAGCGCTCTT & 57.3 & \multirow{2}{*}{-837 to -924} & \multirow{2}{*}{88} \\
\hline SBE4_RIGHT & CATGGATCCCTGAGGGTG & 59.6 & & \\
\hline
\end{tabular}

GW6471 + DBP, WY14643 + DBP, or SB431542 + DBP treatments. Western/IP cell lysis buffer $(20 \mathrm{mM}$, pH 7.5 Tris, $150 \mathrm{mM} \mathrm{NaCl}, 1 \%$ Triton $\mathrm{X}-100$, sodium pyrophosphate, $\beta$ glycerophosphate, EDTA, $\mathrm{Na}_{3} \mathrm{VO}_{4}$, and leupeptin) was used as the protein extraction buffer. Protein concentrations were determined by a BCA protein assay kit. Then, 20 to $40 \mu \mathrm{g}$ sample protein was loaded onto $5 \%-12 \%$ sodium dodecyl sulfate polyacrylamide gels for electrophoresis (SDS-PAGE). Proteins in the gel were either transferred to polyvinylidene fluoride (PVDF) membranes at $18 \mathrm{~V}$ for 30 min using a TransBlotting SD Semi-Dry Electrophoretic Transfer Cell (BioRad, USA) or transferred to PVDF or nitrocellulose membranes by wet transferring at $80 \mathrm{~V}$ or $70 \mathrm{~V}$ for $2 \mathrm{~h}$ at $4^{\circ} \mathrm{C}$ or in an ice-water containing container. Transferred membranes were blocked by 5\% skim milk powder in TBST for 1 to $2 \mathrm{~h}$ at room temperature. First, antibodies were incubated with the membrane at $4^{\circ} \mathrm{C}$ overnight. The dilution ratio for the actin antibody was 1:1000; for other antibodies, it was 1:500. After three washes with $0.1 \%$ TBST for $5 \mathrm{~min}$ each, secondary antibodies were incubated with the membrane at room temperature for $1 \mathrm{~h}$ or first incubated at $4^{\circ} \mathrm{C}$ for $4 \mathrm{~h}$ then incubated at room temperature for $30 \mathrm{~min}$ or $1 \mathrm{~h}$. Dilution ratios of secondary antibodies were all $1: 1000$. Finally, membranes were washed with $0.1 \%$ TBST for three times, $5 \mathrm{~min}$ each. The signal was developed using an enhanced chemiluminescent kit purchased from Millipore Corporation (Billerica, MA, USA). FUSION FX5 Spectra (Vilber, France) was used to image the membranes. Densitometric analyses of immunoblots were performed by Image J software. Phosphoprotein and total protein levels were normalized by actin.

2.7. Immunofluorescence Assays. Confocal culture dishes (20 mm diameters, 801001, Corning, New York, USA) were used to perform the immunofluorescence experiments. After treatment for $24 \mathrm{~h}$, SCs were fixed in $4 \%$ paraformaldehyde (PFA) for $15 \mathrm{~min}$ and then treated with $0.1 \%$ Triton $\mathrm{X}-100$ (diluted with phosphate-buffered saline). After three washes with $\mathrm{PBS}$, fixed cells were incubated with vimentin antibody $(1: 500)$ at $4^{\circ} \mathrm{C}$ overnight. After another three washes with PBS, cells were incubated with DyLight 488 AffiniPure Goat Anti-Mouse $\operatorname{IgG}(\mathrm{H}+\mathrm{L})$ secondary antibody $(1: 1000)$ at room temperature for $1 \mathrm{~h}$. Then, the cells were incubated with DAPI for $30 \mathrm{~min}$ and washed with PBS three times. Leica TCS-SP5 confocal laser scanning microscope (Leica, Mannheim, Germany) was used to visualize the distribution of vimentin.

2.8. Immunocytochemical Assays. SCs were cultured in 48well plates, and, following the different treatments, cells were fixed in 4\% PFA for $15 \mathrm{~min}$. After three washes with PBS, cells were treated with $0.1 \%$ Triton X-100 in PBS for $10 \mathrm{~min}$. Then, cells were treated with $\mathrm{H}_{2} \mathrm{O}_{2}$ for $10 \mathrm{~min}$. After three washes with PBS, cells were incubated with $5 \%$ bovine serum albumin in PBS at room temperature for $1 \mathrm{~h}$. Then, cells were incubated with vimentin antibody at $4^{\circ} \mathrm{C}$ overnight. Following three washes with PBS, cells were incubated with horseradish peroxidase- (HRP-) labeled anti-mouse secondary antibody (ZSBiO, Beijing, China) for $1 \mathrm{~h}$ at room temperature. After 4 washes, cells were incubated with DABchromogen and observed under the microscope until the appropriate brown color appeared. Then, cells were washed thoroughly with PBS. A Nikon Eclipse TE2000 S inverted microscope under 200x original magnification and Nikon digital sight (Nikon, Japan) were used to capture pictures.

2.9. Statistical Analysis of Western Blotting, Real-Time PCR, and ChIP-qPCR Results. Differences between groups were evaluated by one-way analysis of variance (ANOVA), followed by the Holm-Sidak test using Sigma Stat 3.5 software (Sigma-Aldrich, St. Louis, MO, USA). $P<0.05$ was considered to be statistically significant.

\section{Results}

3.1. Role of Smad2/3 in Regulating Vimentin $m R N A$ Expression. Real-time PCR was used to measure vimentin mRNA expression in control and DBP-, Smad2/3 inhibitor(SB431542-), and DBP + SB431542-treated SCs. DBP-exposed SCs presented significant vimentin mRNA levels increase to $1.22 \pm 0.009$-fold variation relative to cells cultured in control conditions (Figure 1(a)), and SB431542 + DBP- or SB431542treated SCs significantly decreased vimentin mRNA levels to 


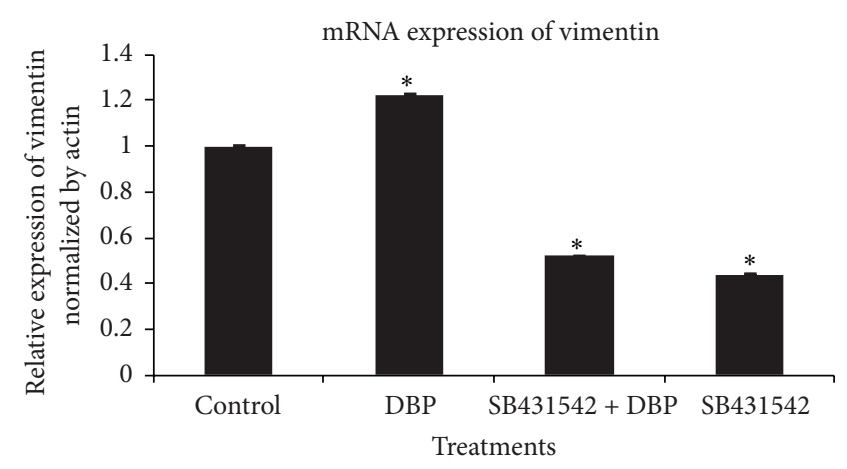

(a)

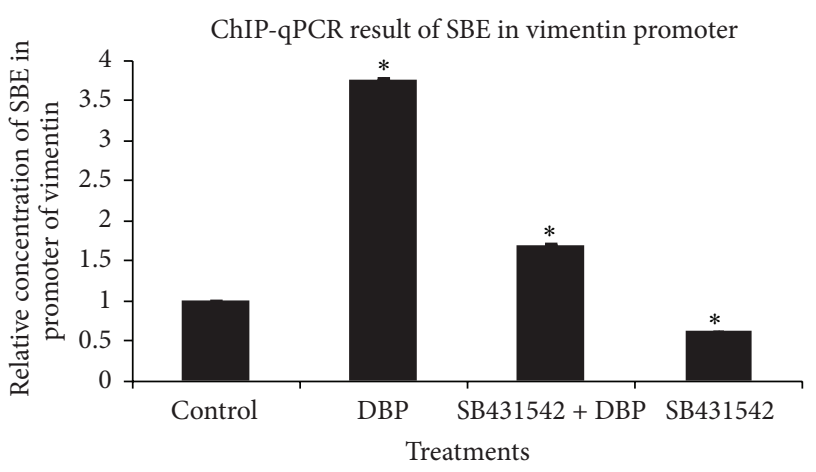

(b)

FIGURE 1: Real-time PCR of vimentin and ChIP-qPCR of Smad binding element (SBE) in the promoter region of vimentin in control and DBP-, SB431542 + DBP-, and SB431542-treated SCs at $24 \mathrm{~h}$. (a) Real-time PCR of vimentin in the indicated SCs. (b) ChIP-qPCR of SBE in the vimentin promoter in the indicated SCs. $P<0.05$ was considered statistically significant.

$0.52 \pm 0.002$ - or $0.44 \pm 0.004$-fold variation relative to SCs cultured in control conditions, respectively. We designed four pairs of primers to amplify SBE-containing sequences in the promoter region of vimentin. The most efficient pair of primers was selected to perform the ChIP-qPCR experiment. As showed in Figure 1(b), binding of $\mathrm{p}-\mathrm{Smad} 2 / 3$ to the SBE of vimentin in DBP-treated SCs significantly increased to $3.77 \pm 0.009$-fold variation relative to SCs cultured in control conditions, and the inhibition of Smad2/3 by SB431542 could significantly decrease the binding of $\mathrm{p}$-Smad2/3 to the SBE of vimentin to $1.70 \pm 0.01$-fold variation in SB431542 + DBPtreated SCs and to $0.63 \pm 0.003$-fold variation in SB431542treated SCs relative to SCs cultured in control conditions. ChIP-qPCR results were consistent with the real-time PCR results. In summary, these findings indicate that Smad2/3 upregulated vimentin mRNA expression in DBP-exposed SCs.

3.2. Role of Smad2/3 in Regulating Vimentin Protein Expression. Western blotting was used to detect the activity of p-Smad2/3 in DBP-treated SCs, and phosphorylated and soluble vimentin were detected in the DBP- and SB431542+ DBP-treated SCs. As showed in Figures 2(a) and 2(d), relative concentrations of total Smad2/3 protein compared to actin remained stable within $24 \mathrm{~h}$ in DBP-treated SCs; relative concentration of $\mathrm{p}-\mathrm{Smad} 2 / 3$ compared to actin in DBP-treated SCs was significantly increased to $1.53 \pm 0.002$-fold variation at $1 \mathrm{~h}, 2.69 \pm 0.0005$-fold variation at $3 \mathrm{~h}, 1.87 \pm 0.0009$ fold variation at $6 \mathrm{~h}, 1.94 \pm 0.006$-fold variation at $12 \mathrm{~h}$, and $2.37 \pm 0.0002$-fold variation at $24 \mathrm{~h}$ relative to SCs cultured in control conditions, respectively. To determine the effect of Smad2/3 on phosphorylated and soluble vimentin, western blotting was performed. As showed in Figures 2(b) and 2(e), phosphorylated vimentin levels in DBP-treated SCs increased to $1.28 \pm 0.009$-fold variation at $1 \mathrm{~h}$, to $1.30 \pm$ 0.03 -fold variation at $3 \mathrm{~h}$, to $1.21 \pm 0.003$-fold variation at $6 \mathrm{~h}$, and to $1.11 \pm 0.01$-fold variation at $12 \mathrm{~h}$ and then decreased to $0.71 \pm 0.03$-fold variation at $24 \mathrm{~h}$ relative to SCs at $0 \mathrm{~h}$. As showed in Figures 2(c) and 2(e), phosphorylated vimentin levels increased in SB431542 + DBP-treated cells to
$1.21 \pm 0.002$-fold variation at $1 \mathrm{~h}$ and then decreased to $0.83 \pm$ 0.001 -fold variation at $3 \mathrm{~h}$, to $0.70 \pm 0.004$-fold variation at $6 \mathrm{~h}$, to $0.56 \pm 0.007$-fold variation at $12 \mathrm{~h}$, and to $0.21 \pm 0.005$ fold variation at $24 \mathrm{~h}$ relative to SCs at $0 \mathrm{~h}$. Phosphorylated vimentin levels were significantly lower at each time point in SB431542 + DBP-treated than DBP-treated cells $(P<0.05)$. The relative quantity of soluble vimentin to actin in DBPtreated SCs increased to $1.76 \pm 0.006$-fold variation at $1 \mathrm{~h}$, to $1.75 \pm 0.008$-fold variation at $3 \mathrm{~h}$, to $1.77 \pm 0.004$-fold variation at $6 \mathrm{~h}$, to $2.20 \pm 0.01$-fold variation at $12 \mathrm{~h}$, and to $1.67 \pm$ 0.02 -fold variation at $24 \mathrm{~h}$ relative to SCs at $0 \mathrm{~h}$. Soluble vimentin in SB431542 + DBP-treated SCs decreased to $1.04 \pm$ 0.003 -fold variation at $1 \mathrm{~h}$, to $0.84 \pm 0.002$-fold variation at $3 \mathrm{~h}$, to $0.89 \pm 0.001$-fold variation at $6 \mathrm{~h}$, to $0.77 \pm 0.002$-fold variation at $12 \mathrm{~h}$, and to $0.80 \pm 0.001$-fold variation at $24 \mathrm{~h}$, relative to SCs at $0 \mathrm{~h}$. Soluble vimentin levels were significantly higher in the DBP-treated SCs than the SB431542 + DBP-treated cells at each time point $(P<0.05)$. In summary, Smad2/3 affected the phosphorylation and solubility of vimentin in DBP-exposed SCs.

3.3. Relationship between PPAR $\alpha$ and Smad2/3 in DBPTreated SCs. An antagonist (GW6471) and an agonist (WY14643) of PPAR $\alpha$ were used to investigate the effect of $\operatorname{PPAR} \alpha$ on the activity of $\operatorname{Smad} 2 / 3$. As shown in Figures $3(\mathrm{a})$ and 3(b), the relative quantity of $\mathrm{p}-\mathrm{Smad} 2 / 3$ to actin in WY14643 + DBP-treated SCs increased to $1.16 \pm 0.003$ fold variation at $1 \mathrm{~h}$, to $1.03 \pm 0.008$-fold variation at $3 \mathrm{~h}$, to $1.36 \pm 0.003$-fold variation at $6 \mathrm{~h}$, to $1.04 \pm 0.004$-fold variation at $12 \mathrm{~h}$, and to $1.35 \pm 0.002$-fold variation at $24 \mathrm{~h}$ relative to $\mathrm{SCs}$ at $0 \mathrm{~h}$. The relative quantity of $\mathrm{p}-\mathrm{Smad} 2 / 3$ to actin in GW6471 + DBP-treated SCs increased to $1.11 \pm 0.01$-fold variation at $1 \mathrm{~h}$ and then decreased to $0.63 \pm 0.004$-fold variation at $3 \mathrm{~h}$, to $0.63 \pm 0.007$-fold variation at $6 \mathrm{~h}$, to $0.85 \pm 0.003$-fold variation at $12 \mathrm{~h}$, and to $0.39 \pm 0.004$-fold variation at $24 \mathrm{~h}$ relative to SCs at $0 \mathrm{~h}$. The relative quantity of p-Smad2/3 was significantly higher in WY14643 + DBPtreated SCs than GW6471 + DBP-treated cells at each time point $(P<0.05)$. Smad2/3 levels in the WY14643 + DBPtreated SCs increased to $1.30 \pm 0.1$-fold variation at $1 \mathrm{~h}$, to 


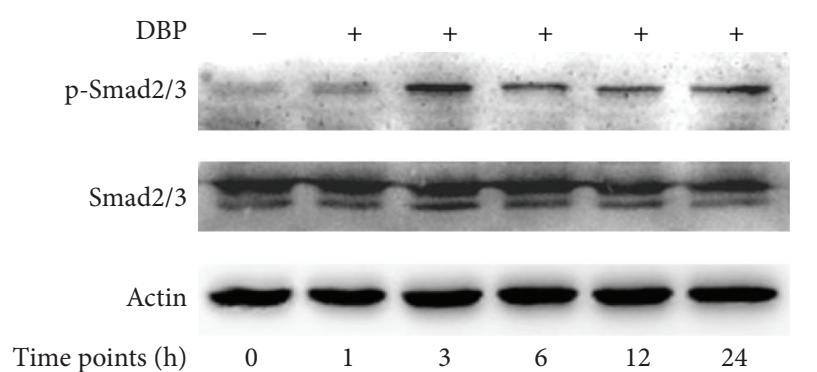

(a)

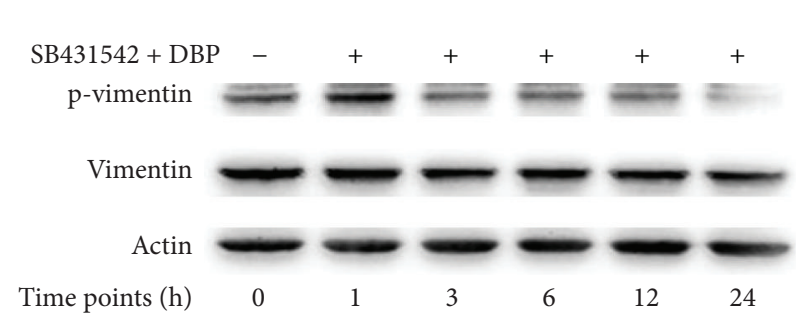

(c)

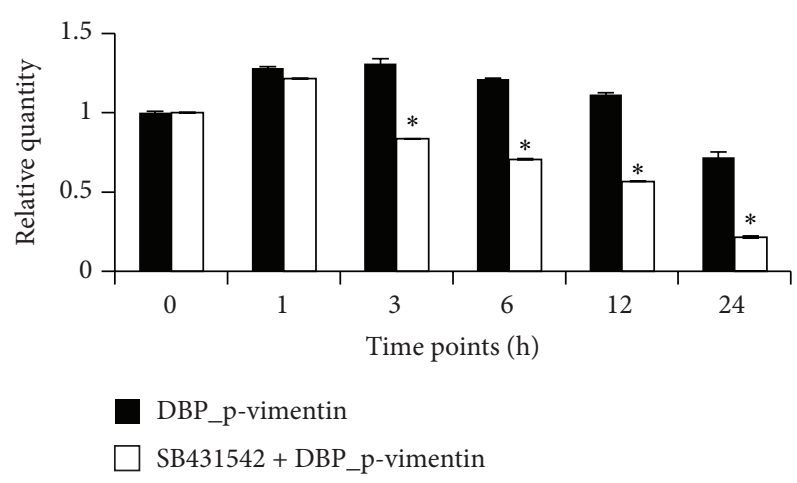

(e)

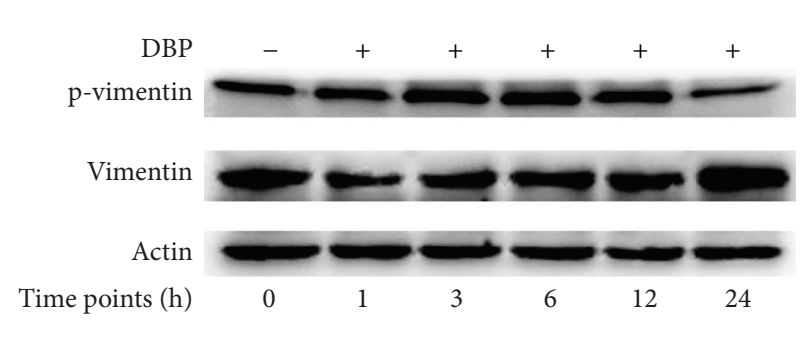

(b)

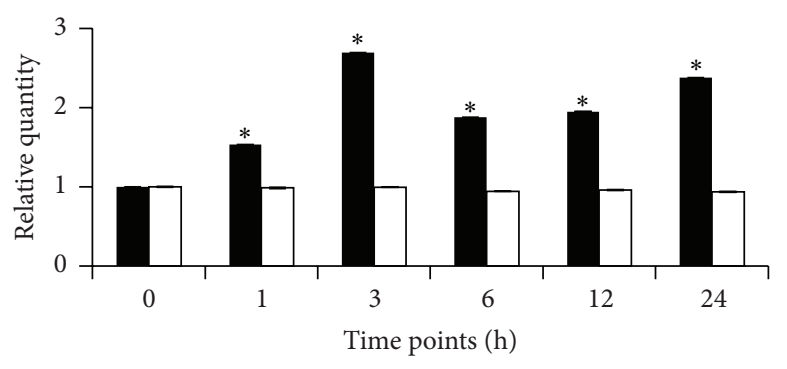

p-Smad2/3_DBP

Total_Smad2/3_DBP

(d)

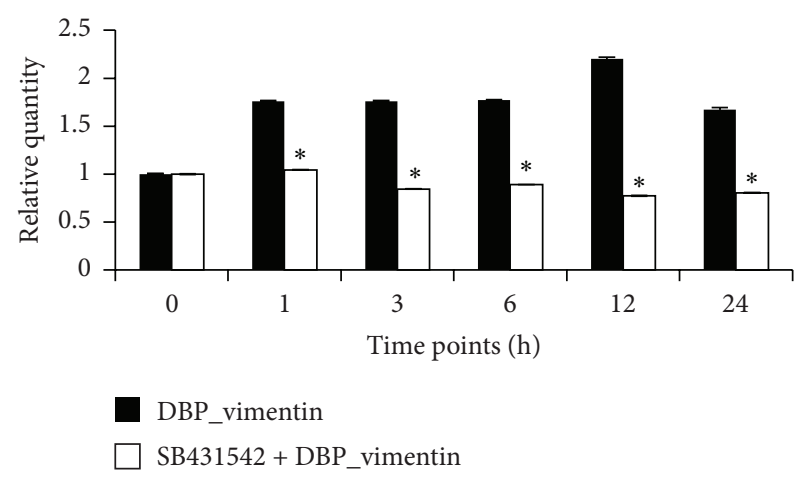

(f)

FIGURE 2: Effects of Smad2/3 on phosphorylation and expression of vimentin in DBP-treated SCs at 0, 1, 3, 6, 12, and 24 h. (a), (b), and (c) show western blotting results of p-Smad2/3, Smad2/3, p-vimentin, vimentin, and actin in DBP- or SB431542 + DBP-treated SCs at different time points. (d), (e), and (f) show the relative quantitative analysis of western blotting results by Image J software. $P<0.05$ was considered statistically significant.

$1.09 \pm 0.006$-fold variation at $3 \mathrm{~h}$, and to $1.02 \pm 0.003$-fold variation at $6 \mathrm{~h}$ and decreased to $0.91 \pm 0.004$-fold variation at $12 \mathrm{~h}$ and to $0.56 \pm 0.003$-fold variation at $24 \mathrm{~h}$ relative to $\mathrm{SCs}$ at $0 \mathrm{~h}$. Smad2/3 levels in the GW6471 + DBP-treated SCs increased to $1.16 \pm 0.01$-fold variation at $1 \mathrm{~h}$, to $1.18 \pm 0.01$ fold variation at $6 \mathrm{~h}$, and to $1.02 \pm 0.008$-fold variation at $12 \mathrm{~h}$ and decreased to $0.88 \pm 0.01$-fold variation at $3 \mathrm{~h}$ and to $0.94 \pm 0.02$-fold variation at $24 \mathrm{~h}$ relative to SCs at $0 \mathrm{~h}$. There were no significant differences in levels of $\mathrm{Smad} 2 / 3$ between WY14643 + DBP-treated and GW6471 + DBP-treated SCs at $1 \mathrm{~h}, 6 \mathrm{~h}$, and $12 \mathrm{~h}(P<0.05)$. The level of Smad2/3 was significantly $(P<0.05)$ higher in WY14643 + DBP-treated than GW6471 + DBP-treated SCs at $3 \mathrm{~h}$ and less at $24 \mathrm{~h}$.

In addition, an inhibitor of p-Smad2/3 (SB431542) was used to assess the influence of $\operatorname{Smad} 2 / 3$ on the activity of
PPAR $\alpha$. As shown in Figures 3(c) and 3(d), PPAR $\alpha$ levels in DBP-treated SCs increased to $1.16 \pm 0.002$-fold variation at $1 \mathrm{~h}$, to $2.54 \pm 0.002$-fold variation at $3 \mathrm{~h}$, to $1.76 \pm 0.003$-fold variation at $6 \mathrm{~h}$, and to $1.81 \pm 0.005$-fold variation at $12 \mathrm{~h}$ and then decreased to $0.62 \pm 0.001$-fold variation at $24 \mathrm{~h}$ relative to SCs at $0 \mathrm{~h}$; the relative quantity of PPAR $\alpha$ in SB431542+ DBP-treated cells increased to $1.17 \pm 0.006$-fold variation at $1 \mathrm{~h}$ and then decreased to $0.77 \pm 0.003$-fold variation at $3 \mathrm{~h}$, to $0.79 \pm 0.004$-fold variation at $6 \mathrm{~h}$, to $0.48 \pm 0.004$-fold variation at $12 \mathrm{~h}$, and to $0.50 \pm 0.002$-fold variation at $24 \mathrm{~h}$ relative to SCs at $0 \mathrm{~h}$. PPAR $\alpha$ levels were significantly $(P<$ 0.05) higher in DBP-treated SCs than SB431542 + DBPtreated cells at $3 \mathrm{~h}, 6 \mathrm{~h}, 12 \mathrm{~h}$, and $24 \mathrm{~h}$. This result suggested that DBP could activate $\operatorname{PPAR} \alpha$, and the activation of $\operatorname{PPAR} \alpha$ in turn activated $\mathrm{p}-\mathrm{Smad} 2 / 3$, initiating a positive 

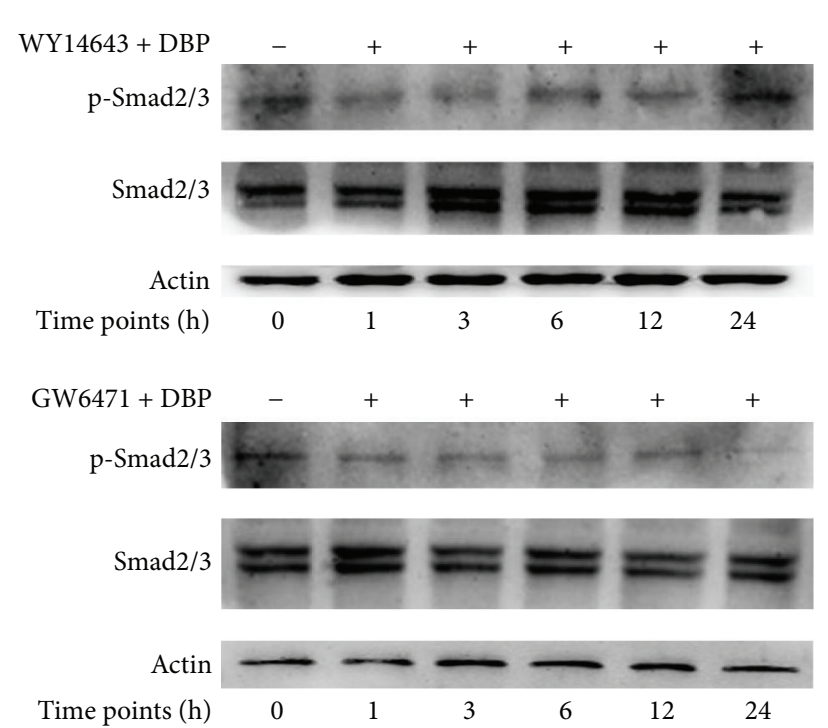

(a)

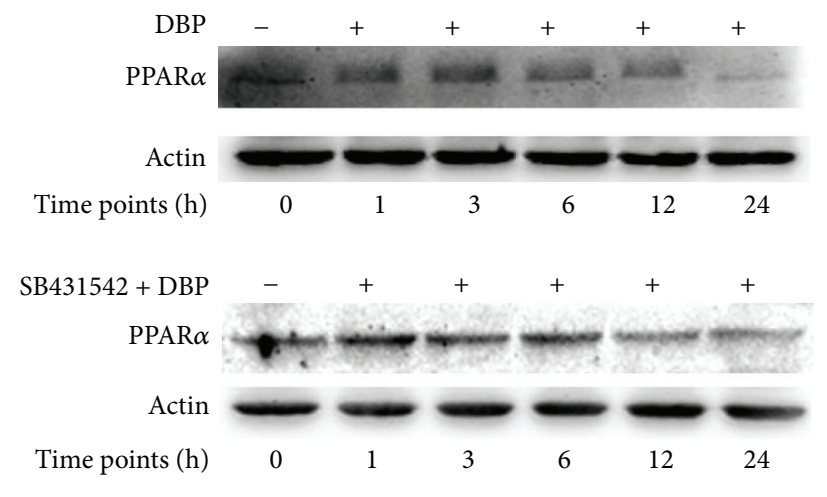

(c)

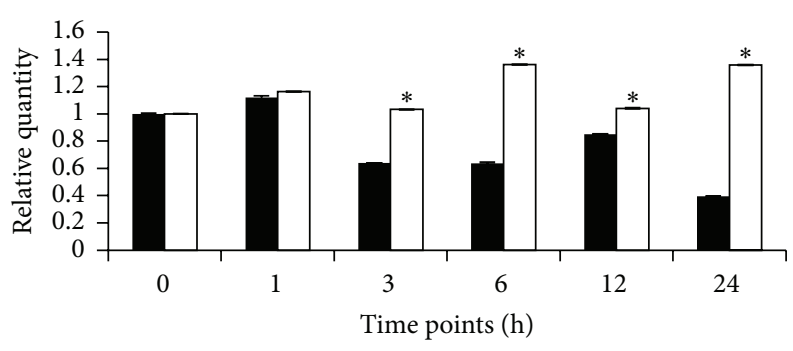

- p-Smad2/3_GW6471 + DBP

$\square$ p-Smad2/3_WY14643 + DBP

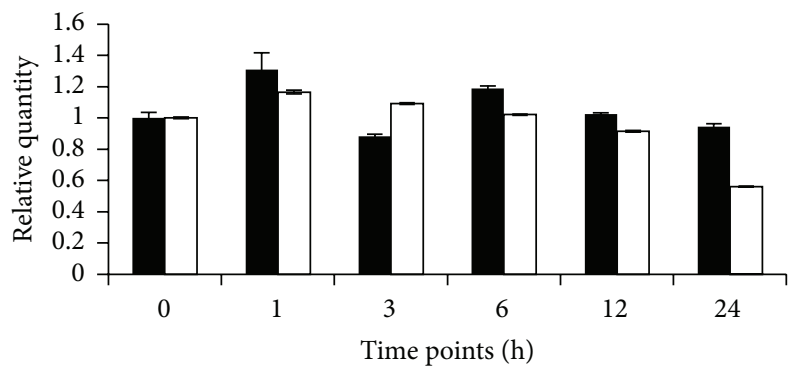

- Smad2/3_GW6471 + DBP

$\square$ Smad2/3_WY14643 + DBP

(b)

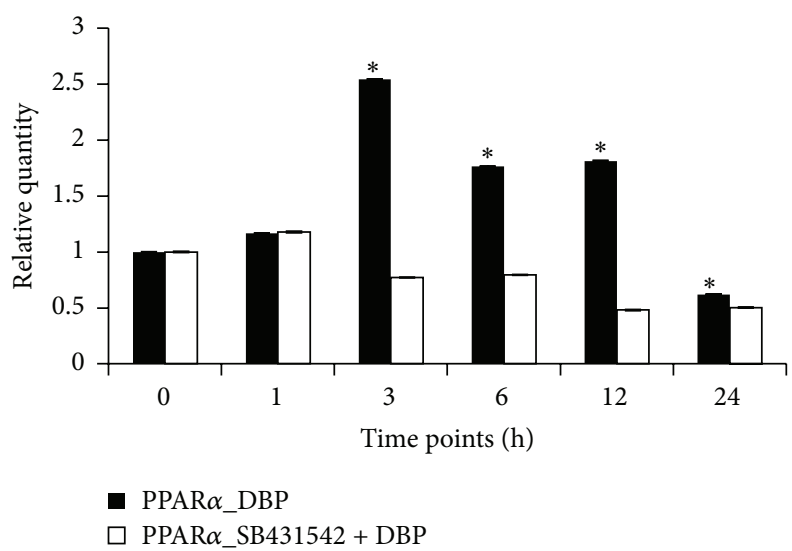

(d)

FIGURE 3: Relationship between PPAR $\alpha$ and Smad2/3 in DBP-treated SCs. GW6471, WY14643, and SB431542 were added to the cultural medium $2 \mathrm{~h}$ before addition of DBP, respectively. Western blotting was used to test levels of $\mathrm{p}-\mathrm{Smad} 2 / 3$ and Smad2/3 in WY14643 + DBPand GW6471 + DBP-treated SCs (as shown in (a)) and levels of PPAR $\alpha$ in DBP- and SB431542 + DBP-treated SCs, respectively (as shown in (c)). (b) and (d) show the relative quantitative analysis of parts (a) and (c), respectively. $P<0.05$ was considered statistically significant.

feedback loop with PPAR $\alpha$. In summary, WY14643 induced the activity of Smad2/3, GW6471 inhibited the activity of Smad2/3, and SB431542 inhibited the activity of PPAR $\alpha$ in DBP-exposed SCs.

\subsection{Distribution of Vimentin in DBP- and SB431542+DBP-} Treated SCs at $24 \mathrm{~h}$. Immunofluorescence and immunocytochemical experiments were performed to detect the distribution of vimentin in control and DBP- and DBP + SB431542treated cells at $24 \mathrm{~h}$. As shown in Figures 4(a) and 4(d), vimentin was distributed regularly in the control group and was mainly present as a network structure, with abnormal aggregated vimentin seldom observed. As shown in Figures 4 (b) and 4(e), regular distribution of vimentin was disrupted in DBP-treated cells, abnormal aggregated vimentin was partially distributed to regions of the cell, and a large proportion of the cells showed concentrated vimentin around the nucleus. As shown in Figures 4(c) and 4(f), vimentin in SB431542 + DBP-treated SCs was abundantly present as irregular long filamentous structures which differed from the DBP-treated cells. In summary, SB431542 did not reverse the collapse of vimentin induced by DBP but triggered the distribution of vimentin as irregular long filaments. 


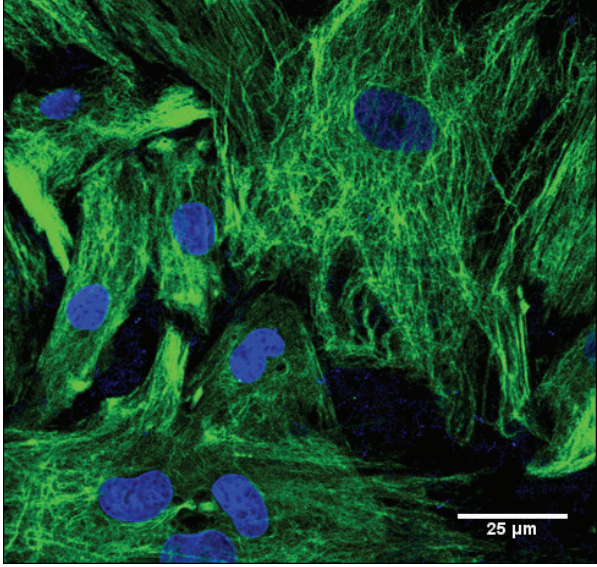

(a)

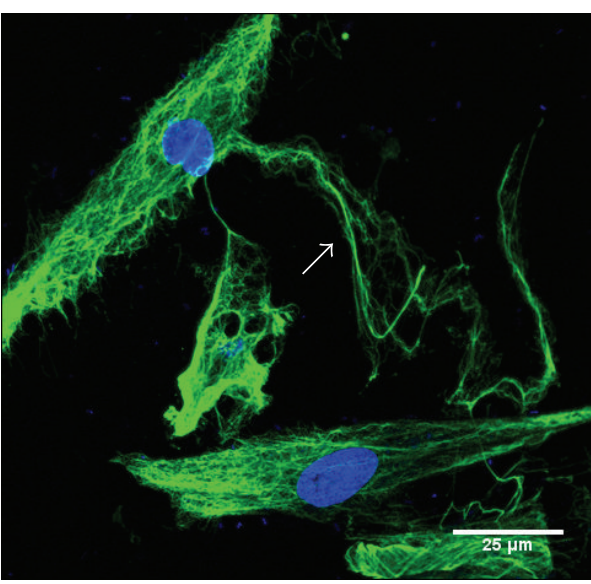

(c)

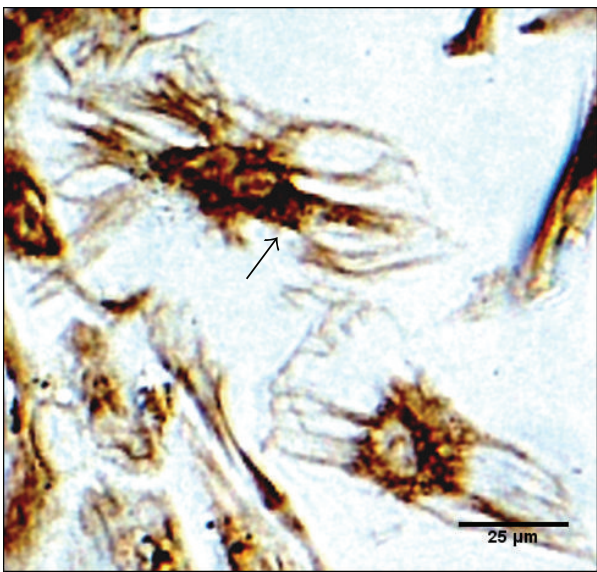

(e)

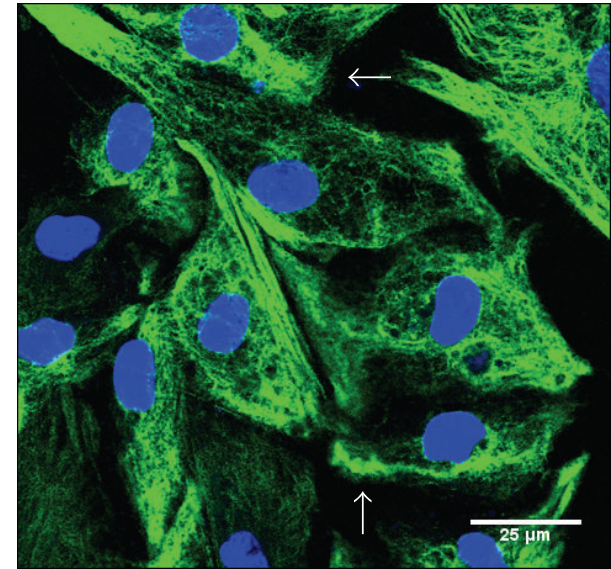

(b)

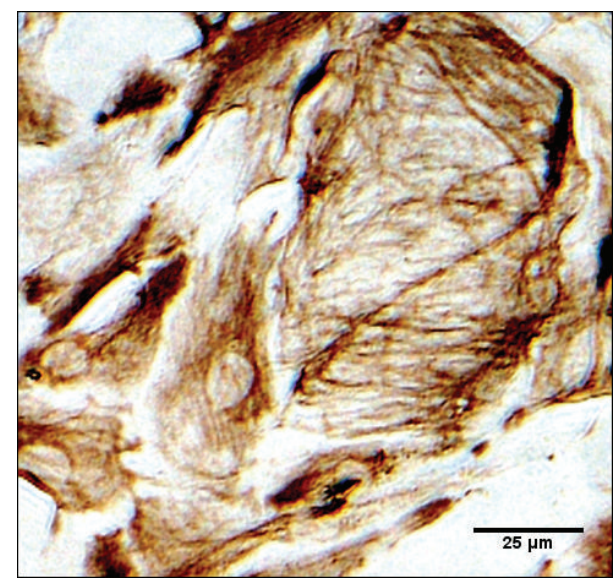

(d)

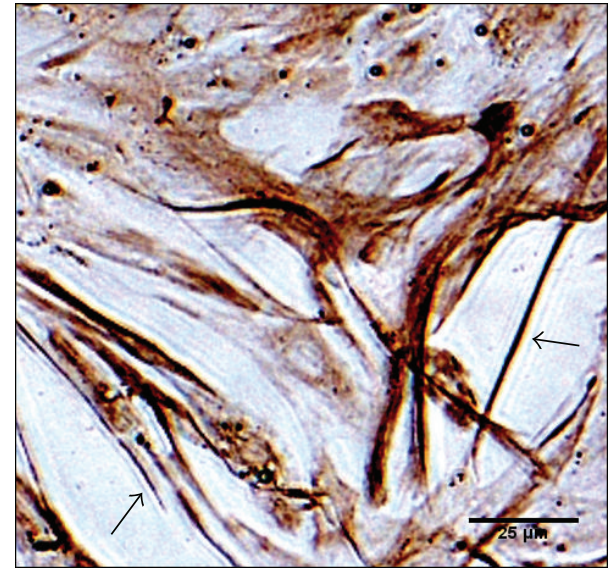

(f)

FIGURE 4: Immunofluorescence and immunocytochemical experiments of vimentin in control and DBP- and SB431542 + DBP-treated SCs at $24 \mathrm{~h}$. (a) and (d) represent the control group; (b) and (e) represent the DBP-treated group; (c) and (f) represent the SB431542 + DBP-treated group (magnification: 200x). The distribution of vimentin showed abnormal aggregation in subregions of SCs (as shown by arrows) compared with the control group. The distribution of vimentin in the SB431542 + DBP-treated group showed many irregular long filamentous structures. 


\section{Discussion}

Spermatogenesis occurs in the seminiferous tubules, and SCs are unique somatic cells in the seminiferous tubules [26] that provide structural and nutritional support during the process of germ cell maturation [27]. Vimentin is an important component of the desmosome [28], and disruption of the vimentin cytoskeleton by DBP leads to dysfunction of the desmosomes [24]. Without the structural support and nutritional supply from SCs, germ cells are prone to apoptosis [29].

Our previous results demonstrated that the increased phosphorylation of vimentin by $\operatorname{PPAR} \alpha$ was the main mechanism of the disruption of vimentin in SCs [12]. However, whether the expression of vimentin is also regulated by $\operatorname{PPAR} \alpha$ is still not clear. In this study, we investigated the role of $S m a d 2 / 3$ in regulating vimentin $m R N A$ expression and the relationship of $\operatorname{Smad} 2 / 3$ and $\operatorname{PPAR} \alpha$ in vimentin distribution in SCs.

Our qRT-PCR results showed that vimentin mRNA expression was upregulated in DBP-exposed SCs at $24 \mathrm{~h}$. A previous microarray study showed that vimentin was upregulated in DBP-treated rat testes at gestational day 20 (GEO accession number: GSE13550). A previous proteomics study also showed that vimentin was upregulated in DBP-exposed rat testes [13]. These results indicated that vimentin expression was stimulated by DBP. Previous studies have indicated that $S m a d 2 / 3$ regulates the expression of vimentin, and the targets were bound by $\mathrm{p}-\mathrm{Smad} 2 / 3$ at SBE-specific sequence GTCTG or CAGAC $[30,31]$. In this study, we found an SBE sequence in the promoter of vimentin which was located at -837 to -924 bp relative to the transcriptional start site by ChIP-qPCR. Moreover, 12 bp downstream of our selected target region for the ChIP-qPCR assay is an AP1 target site. The AP1 site may facilitate the binding of $\mathrm{p}-\mathrm{Smad} 2 / 3$ to its target sequence [17]. We hypothesized that $\mathrm{Smad} 2 / 3$ interacts with other transcriptional factors in regulating the expression of vimentin.

Next, we investigated the influence of $S \operatorname{mad} 2 / 3$ on the phosphorylation and solubility of vimentin. The results (as shown in Figures 2(b), 2(c), 2(e), and 2(f)) demonstrated that the inhibition of Smad2/3 had an inhibitory effect on the phosphorylation of vimentin compared with DBP-treated SCs. The effect of Smad2/3 on the solubility of vimentin was apparent as the relative concentration of soluble vimentin decreased significantly $(P<0.05)$ in a time-dependent manner in SB431542 + DBP-treated SCs. This was consistent with previous studies $[14,15,32,33]$. In these studies, the upregulation of vimentin was closely related to the stimulation of Smad2/3, and SB431542 treatment directly inhibited the expression of vimentin. These results suggested that the regulation of vimentin expression by $\operatorname{Smad} 2 / 3$ may be a universal mechanism.

To illuminate the relationship between PPAR $\alpha$ and Smad2/3, GW6471, WY14643, and SB431542 were used. The results showed that the activity of $S m a d 2 / 3$ was promoted by WY14643 and inhibited by GW6471. The relationship between PPAR $\alpha$ and Smad2/3 is similar to a previous study, where TGF $\beta 1$-induced $\alpha$-SMA was elevated in the WY14643 pretreated group, while it was inhibited in the GW6471 pretreated group [34]. Another study showed that WY14643 could upregulate the mRNA expression of TGF $\beta$ in lung allografts and spleens [35]. Additionally, SB431542 was used to inhibit the activity of $\mathrm{p}$-Smad2/3, and the results showed that activity of PPAR $\alpha$ was not affected by SB431542 at $1 \mathrm{~h}$ but decreased after $3 \mathrm{~h}$. These results suggested that PPAR $\alpha$ stimulates the activation of $\mathrm{p}-\mathrm{Smad} 2 / 3$ in DBP-exposed SCs, and Smad2/3 may initiate a positive feedback loop with PPAR $\alpha$.

The disrupted vimentin cytoskeleton in DBP-treated SCs was not recovered by SB431542 but showed a new abnormal distribution, mainly consisting of abundant irregular long filamentous structures. Phosphorylation of vimentin in SB431542 + DBP-treated SCs was inhibited compared to the DBP-treated group. SB431542 inhibited the expression of vimentin. Abnormally high and low levels of phosphorylation both affected the dynamic reassembly of vimentin [36]. These two factors may be reasons for the abnormal distribution of vimentin in SB431542 + DBP-treated SCs. Studying the interaction of Smad2/3 with other kinases which affected the posttranslational modifications of vimentin in DBP-treated SCs would be our next objective. The mechanism behind the irregular long filamentous structures of vimentin may involve signaling transduction along these filaments [37].

We determined that abnormal stimulation of the activity of Smad2/3 in SCs by DBP disrupted the dynamic assembly of connections between SCs and the developing spermatids, and the effect of Smad2/3 on vimentin was one aspect of a cascade of responses induced by DBP. Proliferation of SCs is mediated by activin through Smad3; Smad3 knockout mice exhibited delayed SCs maturation $[38,39]$. Sertoli epithelium separates germ cells from testis interstitium and cooperates with peritubular myoid cells to facilitate the spermatogenesis [40]. DBP, as a phthalate, could induce Leydig cells hyperplasia and then deprive the space belonging to SCs [41]. According to a recent study, SCs could be reprogrammed to Leydig cells by Wt1 ablation [42]. Two previous gene array studies showed that Wt1 was downregulated in testes induced by DBP (GSE25196, GSE13550). Upregulation of Vimentin, as a marker of epithelial-to-mesenchyme transformation [43-45], by Smad2/3 induced by DBP in SCs may also trigger the epithelial-to-mesenchyme transformation, disturb the epithelial layer, and affect the stability of blood testes barrier. Disruption of blood testes barrier is one of the major adverse effects induced by DBP [46]. Besides, cross talk of TGF $\beta 1 / \mathrm{Smad} 3$ with orphan nuclear receptor Nur77 was reported to repress the steroidogenesis in Leydig cells [47]. Vimentin participates in the transportation of cholesterol during steroidogenesis [48-50]. Steroidogenesis is disrupted by DBP according to several previous studies [51, 52]. PPAR $\alpha$ was reported to be an indirect transrepressor of SF1 on steroidogenic genes in testes [53]. To some extent, PPAR $\alpha$ may also affect the steroidogenesis by affecting vimentin in DBP-exposed testes cells. Although we performed our experiment in SCs here, there is vimentin in Leydig cells too [54]. So mechanism deduced here may also shed some light on DBP-exposed Leydig cells studies.

A limitation of this research is that we only studied the expression and phosphorylation of vimentin in DBP-exposed 


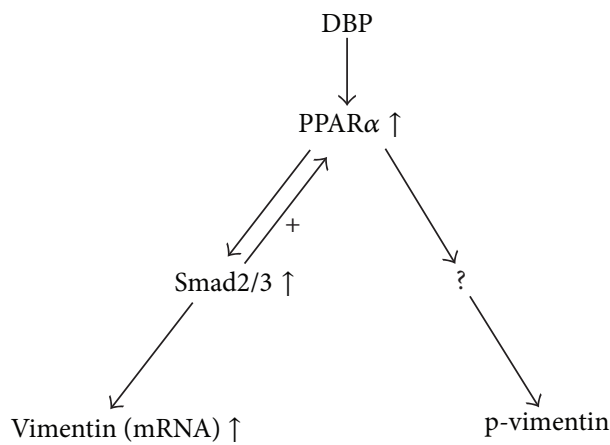

FIgure 5: Schematic diagram of the relationship between PPAR $\alpha$ and $S m a d 2 / 3$ in regulation of vimentin in DBP-exposed SCs. DBP stimulated the activity of PPAR $\alpha$, activated PPAR $\alpha$ promoted the activity of $S \operatorname{mad} 2 / 3$, and activated $S \operatorname{mad} 2 / 3$ upregulated the vimentin mRNA expression. As SB431542 inhibited Smad2/3 and could inhibit PPAR $\alpha$ to some extent, we deduced that $\operatorname{Smad} 2 / 3$ may have a positive feedback response to $\operatorname{PPAR} \alpha$.

SCs. In physiological situations, ubiquitination, glycosylation, acetylation, and many other modifications affect the distribution and functions of vimentin [55]. In future studies, other modifications should be taken into consideration. In vivo studies are also needed to confirm the conclusions deduced from these in vitro studies.

\section{Conclusion}

In this study, we found that $\mathrm{Smad} 2 / 3$ upregulated the expression of vimentin in DBP-exposed SCs. The inhibition of $\operatorname{PPAR} \alpha$ could attenuate the activity of $\operatorname{Smad} 2 / 3$. Smad2/3 may have a positive feedback effect on PPAR $\alpha . \operatorname{Smad} 2 / 3$ and $\operatorname{PPAR} \alpha$ cooperated in regulating the expression, phosphorylation, and distribution of vimentin in DBP-exposed SCs (as shown in the schematic diagram in Figure 5).

\section{Conflict of Interests}

The authors declare that there is no conflict of interests.

\section{Acknowledgments}

This work was supported by the National Natural Science Foundation of China (NSFC), no. 81072319, and Key Program of NSFC (no. 81130051).

\section{References}

[1] A. Boyer, L. Hermo, M. Paquet, B. Robaire, and D. Boerboom, "Seminiferous tubule degeneration and infertility in mice with sustained activation of WNT/CTNNB1 signaling in sertoli cells," Biology of Reproduction, vol. 79, no. 3, pp. 475-485, 2008.

[2] A. J. Drake, S. van den Driesche, H. M. Scott, G. R. Hutchison, J. R. Seckl, and R. M. Sharpe, "Glucocorticoids amplify dibutyl phthalate-induced disruption of testosterone production and male reproductive development," Endocrinology, vol. 150, no. 11, pp. 5055-5064, 2009.
[3] M. Ema and E. Miyawaki, "Adverse effects on development of the reproductive system in male offspring of rats given monobutyl phthalate, a metabolite of dibutyl phthalate, during late pregnancy," Reproductive Toxicology, vol. 15, no. 2, pp. 189194, 2001.

[4] J. S. Fisher, S. Macpherson, N. Marchetti, and R. M. Sharpe, "Human 'testicular dysgenesis syndrome': a possible model using in-utero exposure of the rat to dibutyl phthalate," Human Reproduction, vol. 18, no. 7, pp. 1383-1394, 2003.

[5] J. Bao, M. Wang, X. Ning et al., "Phthalate concentrations in personal care products and the cumulative exposure to female adults and infants in Shanghai," Journal of Toxicology and Environmental Health Part A: Current Issues, vol. 78, no. 5, pp. 325-341, 2015.

[6] J. D. Meeker and K. K. Ferguson, "Urinary phthalate metabolites are associated with decreased serum testosterone in men, women, and children from NHANES 2011-2012," Journal of Clinical Endocrinology and Metabolism, vol. 99, no. 11, pp. 43464352, 2014.

[7] M. G. Alves, T. R. Dias, B. M. Silva, and P. F. Oliveira, "Metabolic cooperation in testis as a pharmacological target: from disease to contraception," Current Molecular Pharmacology, vol. 7, no. 2, pp. 83-95, 2014.

[8] M. G. Alves, L. Rato, R. A. Carvalho, P. I. Moreira, S. Socorro, and P. F. Oliveira, "Hormonal control of Sertoli cell metabolism regulates spermatogenesis," Cellular and Molecular Life Sciences, vol. 70, no. 5, pp. 777-793, 2013.

[9] D. D. Mruk and C. Y. Cheng, "Sertoli-sertoli and sertoli-germ cell interactions and their significance in germ cell movement in the seminiferous epithelium during spermatogenesis," Endocrine Reviews, vol. 25, no. 5, pp. 747-806, 2004.

[10] L.-J. Zhu, S.-D. Zong, D. M. Phillips, A. J. Moo-Young, and C. W. Bardin, "Changes in the distribution of intermediate filaments in rat Sertoli cells during the seminiferous epithelium cycle and postnatal development," Anatomical Record, vol. 248, no. 3, pp. 391-405, 1997.

[11] E. Kleymenova, C. Swanson, K. Boekelheide, and K. W. Gaido, "Exposure in utero to di( $n$-butyl) phthalate alters the vimentin cytoskeleton of fetal rat sertoli cells and disrupts sertoli cellgonocyte contact," Biology of Reproduction, vol. 73, no. 3, pp. 482-490, 2005.

[12] X. Zhang, W. Liu, H. Yang et al., "Inhibition of PPAR $\alpha$ attenuates vimentin phosphorylation on Ser-83 and collapse of vimentin filaments during exposure of rat Sertoli cells in vitro to DBP," Reproductive Toxicology, vol. 50, pp. 11-18, 2014.

[13] A.-M. Bao, X.-M. Man, X.-J. Guo et al., "Effects of di-n-butyl phthalate on male rat reproduction following pubertal exposure," Asian Journal of Andrology, vol. 13, no. 5, pp. 702-709, 2011.

[14] L. Pang, Q. Li, C. Wei et al., "TGF- $\beta 1 /$ Smad signaling pathway regulates epithelial-to-mesenchymal transition in esophageal squamous cell carcinoma: in vitro and clinical analyses of cell lines and nomadic Kazakh patients from northwest Xinjiang, China," PLoS ONE, vol. 9, no. 12, Article ID el12300, 2014.

[15] D. O'Kane, M. V. Jackson, A. Kissenpfennig et al., "SMAD inhibition attenuates epithelial to mesenchymal transition by primary keratinocytes in vitro," Experimental Dermatology, vol. 23, no. 7, pp. 497-503, 2014.

[16] C. Yu, Y. Liu, D. Huang et al., “TGF- $\beta 1$ mediates epithelial to mesenchymal transition via the TGF- $\beta /$ Smad pathway in squamous cell carcinoma of the head and neck," Oncology Reports, vol. 25 , no. 6 , pp. 1581-1587, 2011. 
[17] Y. Wu, X. Zhang, M. Salmon, X. Lin, and Z. E. Zehner, "TGFbetal regulation of vimentin gene expression during differentiation of the $\mathrm{C} 2 \mathrm{C} 12$ skeletal myogenic cell line requires Smads, AP-1 and Sp1 family members," Biochimica et Biophysica ActaMolecular Cell Research, vol. 1773, no. 3, pp. 427-439, 2007.

[18] M. Lydka, B. Bilinska, C. Y. Cheng, and D. D. Mruk, "Tumor necrosis factor $\alpha$-mediated restructuring of the Sertoli cell barrier in vitro involves matrix metalloprotease 9 (MMP9), membrane-bound intercellular adhesion molecule-1 (ICAM-1) and the actin cytoskeleton," Spermatogenesis, vol. 2, no. 4, pp. 294-303, 2014.

[19] P. K. Nicholls, C. A. Harrison, R. B. Gilchrist, P. G. Farnworth, and P. G. Stanton, "Growth differentiation factor 9 is a germ cell regulator of sertoli cell function," Endocrinology, vol. 150, no. 5, pp. 2481-2490, 2009.

[20] Y. Shi, Y. Song, Y. Wang et al., "p, p'-DDE induces apoptosis of rat Sertoli cells via a FasL-dependent pathway," Journal of Biomedicine and Biotechnology, vol. 2009, Article ID 181282, 11 pages, 2009.

[21] L. Su, C. Y. Cheng, and D. D. Mruk, "Adjudin-mediated Sertoligerm cell junction disassembly affects Sertoli cell barrier function in vitro and in vivo," International Journal of Biochemistry and Cell Biology, vol. 42, no. 11, pp. 1864-1875, 2010.

[22] M. Regueira, M. F. Riera, M. N. Galardo, E. H. Pellizzari, S. B. Cigorraga, and S. B. Meroni, "Activation of PPAR $\alpha$ and PPAR $\beta / \delta$ regulates Sertoli cell metabolism," Molecular and Cellular Endocrinology, vol. 382, no. 1, pp. 271-281, 2014.

[23] T. Kawahara, M. Yamashita, K. Ikegami et al., "TGF-beta negatively regulates the BMP2-dependent early commitment of periodontal ligament cells into hard tissue forming cells," PLoS ONE, vol. 10, no. 5, Article ID e0125590, 2015.

[24] M. S. Alam, S. Ohsako, T. W. Tay, N. Tsunekawa, Y. Kanai, and M. Kurohmaru, "Di(n-butyl) phthalate induces vimentin filaments disruption in rat sertoli cells: a possible relation with spermatogenic cell apoptosis," Anatomia, Histologia, Embryologia, vol. 39, no. 3, pp. 186-193, 2010.

[25] M. R. Rogel, P. N. Soni, J. R. Troken, A. Sitikov, H. E. Trejo, and K. M. Ridge, "Vimentin is sufficient and required for wound repair and remodeling in alveolar epithelial cells," The FASEB Journal, vol. 25, no. 11, pp. 3873-3883, 2011.

[26] L. Rato, S. Socorro, J. E. B. Cavaco, and P. F. Oliveira, "Tubular fluid secretion in the seminiferous epithelium: ion transporters and aquaporins in sertoli cells," Journal of Membrane Biology, vol. 236, no. 2, pp. 215-224, 2010.

[27] L. Rato, M. G. Alves, S. Socorro, A. I. Duarte, J. E. Cavaco, and P. F. Oliveira, "Metabolic regulation is important for spermatogenesis," Nature Reviews Urology, vol. 9, no. 6, pp. 330-338, 2012.

[28] A. W. Vogl, K. S. Vaid, and J. A. Guttman, "The Sertoli cell cytoskeleton," Advances in Experimental Medicine and Biology, vol. 636, pp. 186-211, 2008.

[29] T. R. Dias, L. Rato, A. D. Martins et al., "Insulin deprivation decreases caspase-dependent apoptotic signaling in cultured rat sertoli cells," ISRN Urology, vol. 2013, Article ID 970370, 8 pages, 2013.

[30] L. J. C. Jonk, S. Itoh, C.-H. Heldin, P. Ten Dijke, and W. Kruijer, "Identification and functional characterization of a Smad binding element (SBE) in the JunB promoter that acts as a transforming growth factor-beta, activin, and bone morphogenetic protein-inducible enhancer," The Journal of Biological Chemistry, vol. 273, no. 33, pp. 21145-21152, 1998.

[31] S.-J. Chen, W. Yuan, S. Lo, M. Trojanowska, and J. Varga, "Interaction of smad3 with a proximal smad-binding element of the human $\alpha 2$ (I) procollagen gene promoter required for transcriptional activation by TGF- $\beta$," Journal of Cellular Physiology, vol. 183, no. 3, pp. 381-392, 2000.

[32] P. Wang, "Suppression of DACH1 promotes migration and invasion of colorectal cancer via activating TGF- $\beta$-mediated epithelial-mesenchymal transition," Biochemical and Biophysical Research Communications, vol. 460, no. 2, pp. 314-319, 2015.

[33] C. Marmai, R. E. Sutherland, K. K. Kim et al., "Alveolar epithelial cells express mesenchymal proteins in patients with idiopathic pulmonary fibrosis," The American Journal of Physiology-Lung Cellular and Molecular Physiology, vol. 301, no. 1, pp. L71-L78, 2011.

[34] G. Oruqaj, S. Karnati, V. Vijayan et al., "Compromised peroxisomes in idiopathic pulmonary fibrosis, a vicious cycle inducing a higher fibrotic response via TGF- $\beta$ signaling," Proceedings of the National Academy of Sciences, vol. 112, no. 16, pp. E2048E2057, 2015.

[35] J. Yanagisawa, T. Shiraishi, A. Iwasaki et al., "PPAR $\alpha$ ligand WY14643 reduced acute rejection after rat lung transplantation with the upregulation of IL-4, IL-10 and TGF $\beta$ mRNA expression," Journal of Heart and Lung Transplantation, vol. 28, no. 11, pp. 1172-1179, 2009.

[36] R. K. Sihag, M. Inagaki, T. Yamaguchi, T. B. Shea, and H. C. Pant, "Role of phosphorylation on the structural dynamics and function of types III and IV intermediate filaments," Experimental Cell Research, vol. 313, no. 10, pp. 2098-2109, 2007.

[37] D. G. Meckes Jr., N. F. Menaker, and N. Raab-Traub, "Epsteinbarr virus LMP1 modulates lipid raft microdomains and the vimentin cytoskeleton for signal transduction and transformation," Journal of Virology, vol. 87, no. 3, pp. 1301-1311, 2013.

[38] J. C. Young, S. Wakitani, and K. L. Loveland, “TGF- $\beta$ superfamily signaling in testis formation and early male germline development," Seminars in Cell \& Developmental Biology, vol. 45, pp. 94-103, 2015.

[39] C. Itman, C. Small, M. Griswold et al., "Developmentally regulated SMAD2 and SMAD3 utilization directs activin signaling outcomes," Developmental Dynamics, vol. 238, no. 7, pp. 16881700, 2009.

[40] D. R. Archambeault, J. Tomaszewski, A. Joseph, B. T. Hinton, and H. H.-C. Yao, "Epithelial-mesenchymal crosstalk in Wolffian duct and fetal testis cord development," Genesis, vol. 47, no. 1, pp. 40-48, 2009.

[41] N. Hallmark, M. Walker, C. McKinnell et al., "Effects of monobutyl and di(n-butyl) phthalate in vitro on steroidogenesis and Leydig cell aggregation in fetal testis explants from the rat: comparison with effects in vivo in the fetal rat and neonatal marmoset and in vitro in the human," Environmental Health Perspectives, vol. 115, no. 3, pp. 390-396, 2007.

[42] L. Zhang, M. Chen, Q. Wen et al., "Reprogramming of Sertoli cells to fetal-like Leydig cells by Wt1 ablation," Proceedings of the National Academy of Sciences of the United States of America, vol. 112, no. 13, pp. 4003-4008, 2015.

[43] X. Zhai, H. Zhu, W. Wang, S. Zhang, Y. Zhang, and G. Mao, "Abnormal expression of EMT-related proteins, S100A4, vimentin and E-cadherin, is correlated with clinicopathological features and prognosis in HCC," Medical Oncology, vol. 31, no. 6, article 970, 2014.

[44] S. Y. Chaw, A. Abdul Majeed, A. J. Dalley, A. Chan, S. Stein, and C. S. Farah, "Epithelial to mesenchymal transition (EMT) biomarkers-E-cadherin, beta-catenin, APC and Vimentinin oral squamous cell carcinogenesis and transformation," Oral Oncology, vol. 48, no. 10, pp. 997-1006, 2012. 
[45] K. Vuoriluoto, H. Haugen, S. Kiviluoto et al., "Vimentin regulates EMT induction by Slug and oncogenic H-Ras and migration by governing Axl expression in breast cancer," Oncogene, vol. 30, no. 12, pp. 1436-1448, 2011.

[46] Y. Zhou, M. Fukuoka, and A. Tanaka, "Mechanisms of testicular atrophy induced by di- $n$-butyl phthalate in rats. Part 3 . Changes in the activity of some enzymes in the sertoli and germ cells, and in the levels of metal ions," Journal of Applied Toxicology, vol. 10, no. 6, pp. 447-453, 1990.

[47] E. Park, C. Song, J. Park et al., “Transforming growth factor- $\beta 1$ signaling represses testicular steroidogenesis through cross-talk with orphan nuclear receptor Nur7," PLoS ONE, vol. 9, no. 8, Article ID e104812, 2014.

[48] F. Tamari, F. W. Chen, C. Li, J. Chaudhari, and Y. A. Ioannou, "PKC activation in Niemann pick $\mathrm{Cl}$ cells restores subcellular cholesterol transport," PLoS ONE, vol. 8, no. 8, Article ID e74169, 2013.

[49] F. B. Kraemer, V. K. Khor, W.-J. Shen, and S. Azhar, "Cholesterol ester droplets and steroidogenesis," Molecular and Cellular Endocrinology, vol. 371, no. 1-2, pp. 15-19, 2013.

[50] W.-J. Shen, S. K. Zaidi, S. Patel et al., "Ablation of vimentin results in defective steroidogenesis," Endocrinology, vol. 153, no. 7, pp. 3249-3257, 2012.

[51] Z. Xiao-Feng, Q. Nai-Qiang, Z. Jing, L. Zi, and Z. Yang, "Di (n-butyl) phthalate inhibits testosterone synthesis through a glucocorticoid-mediated pathway in rats," International Journal of Toxicology, vol. 28, no. 5, pp. 448-456, 2009.

[52] C. J. Thompson, S. M. Ross, and K. W. Gaido, "Di(n-butyl) phthalate impairs cholesterol transport and steroidogenesis in the fetal rat testis through a rapid and reversible mechanism," Endocrinology, vol. 145, no. 3, pp. 1227-1237, 2004.

[53] S. M. Plummer, D. Dan, J. Quinney et al., "Identification of transcription factors and coactivators affected by dibutylphthalate interactions in fetal rat testes," Toxicological Sciences, vol. 132, no. 2, pp. 443-457, 2013.

[54] S. Wakui, H. Takahashi, T. Mutou et al., "Atypical leydig cell hyperplasia in adult rats with low $\mathrm{T}$ and high $\mathrm{LH}$ induced by prenatal Di(n-butyl) phthalate exposure," Toxicologic Pathology, vol. 41, no. 3, pp. 480-486, 2013.

[55] N. T. Snider and M. B. Omary, "Post-translational modifications of intermediate filament proteins: mechanisms and functions," Nature Reviews Molecular Cell Biology, vol. 15, no. 3, pp. 163-177, 2014. 


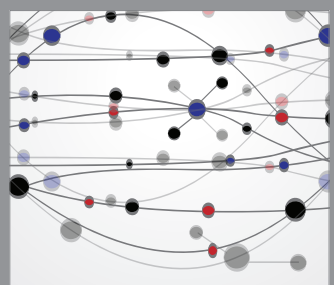

The Scientific World Journal
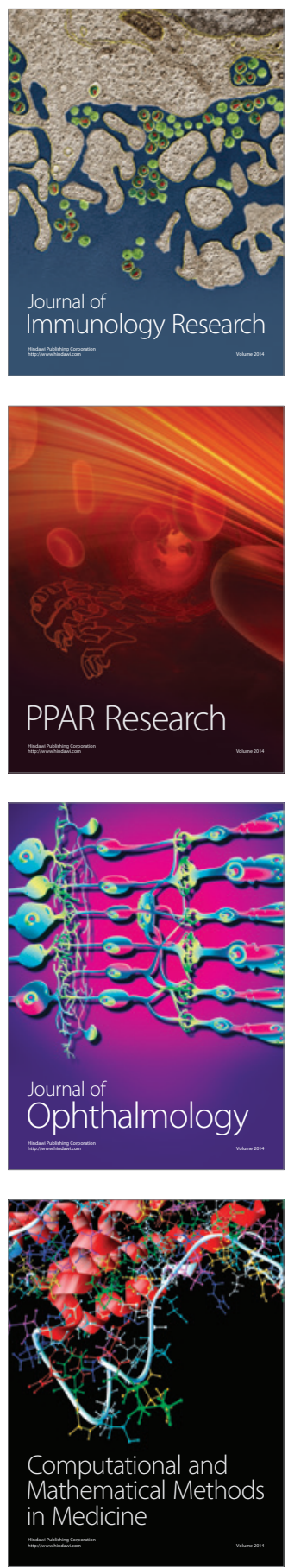

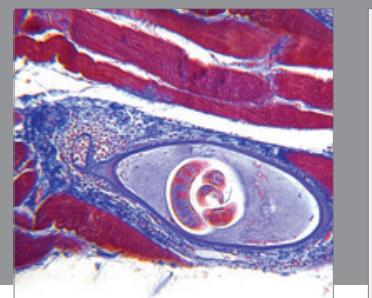

Gastroenterology

Research and Practice
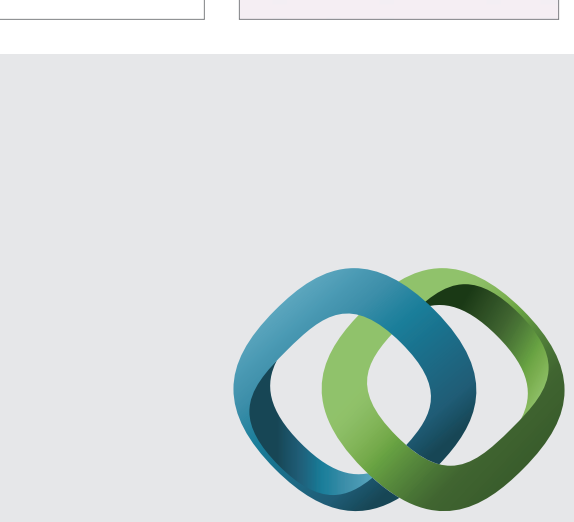

\section{Hindawi}

Submit your manuscripts at

http://www.hindawi.com
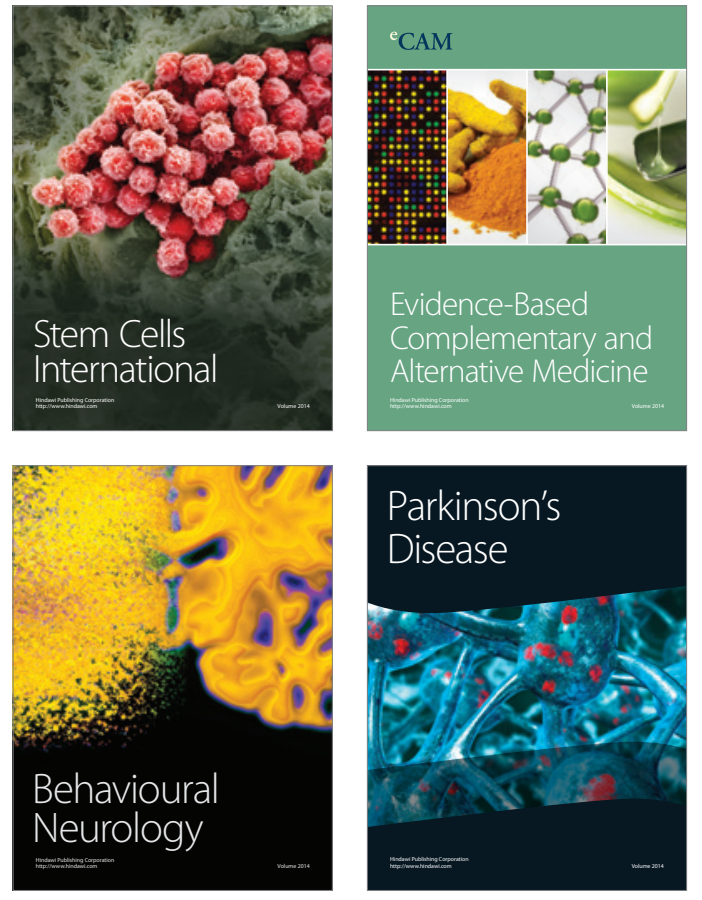
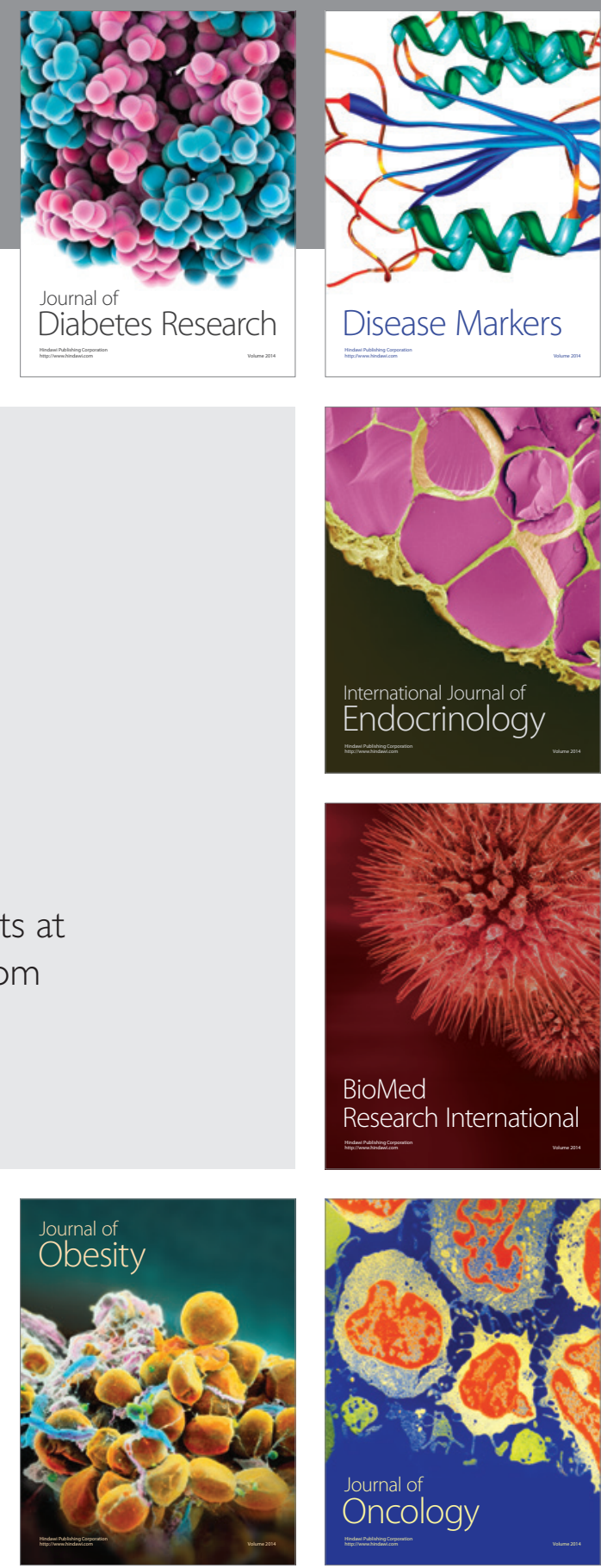

Disease Markers
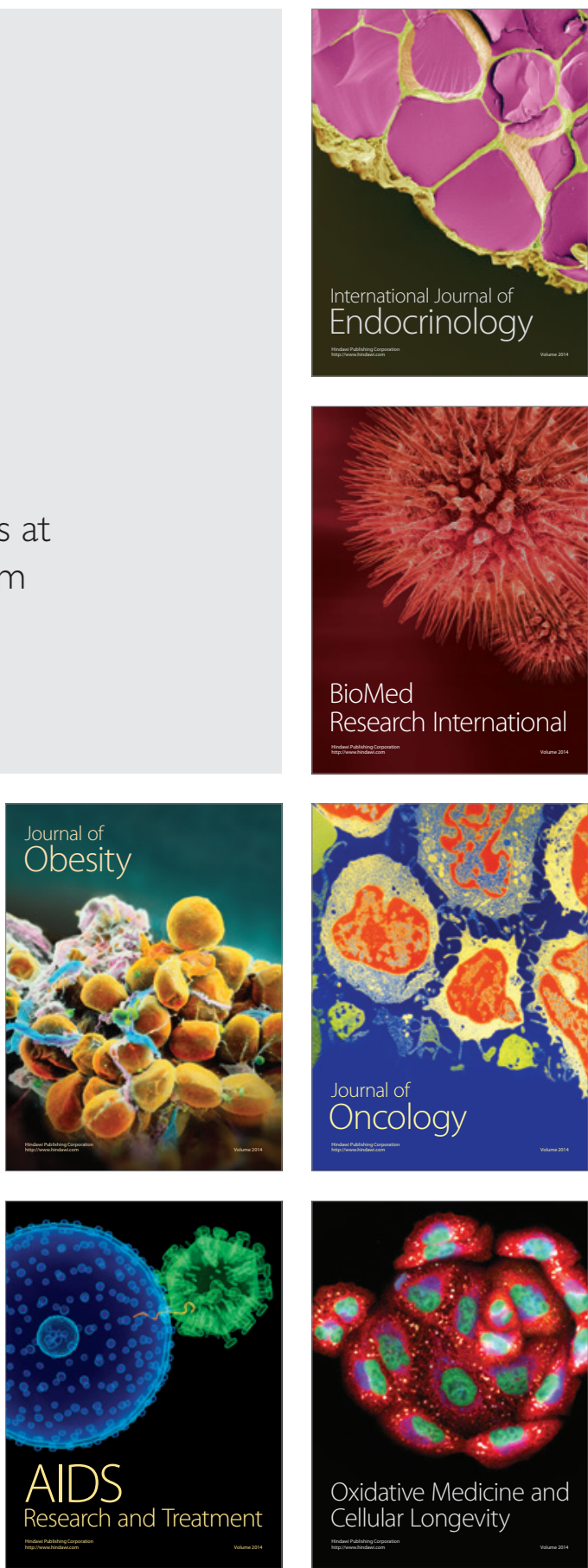